\title{
Chemical analysis reveals sex differences in the preen gland secretion of breeding Blue Tits
}

\author{
Barbara A. Caspers ${ }^{1}$ (1) $\cdot$ Reinaldo Marfull ${ }^{2} \cdot$ Tim Dannenhaus $^{3} \cdot$ Jan Komdeur $^{2}$ (1) $\cdot$ Peter Korsten $^{3}$ (1)
}

Received: 29 March 2021 / Revised: 22 July 2021 / Accepted: 26 July 2021 / Published online: 11 August 2021

(c) The Author(s) 2021

\begin{abstract}
Acoustic and visual signals are well known to play important roles in social communication in birds. Growing evidence suggests that many bird species, including species of songbirds, additionally have a well-developed sense of smell. However, we are still at the beginning of understanding the potential importance of chemical communication in the social lives of birds, for example in mate choice. The secretion of the preen gland may be an important contributor to the chemical phenotype of birds. Here, we report on a first characterisation of the chemical composition of the preen gland secretion of the Blue Tit (Cyanistes caeruleus), a common songbird which is an often used model species in animal behaviour and ecology, in particular also in studies of sexual selection and (extra-pair) mate choice. We found sex differences in the composition of the preen gland secretion in breeding Blue Tits. Females further tended to have a larger number of putative compounds in their secretions compared to males. We briefly discuss the possible implications of these findings and speculate that the chemical composition of the preen gland secretion may be a sexually selected trait in Blue Tits. Our preliminary findings warrant follow-up research into the patterns of within- and among individual variation in the chemical composition of the preen gland secretion as well as the identification of the main chemical compounds involved.
\end{abstract}

Keywords Uropygial gland $\cdot$ VOCs $\cdot$ Avian olfaction $\cdot$ Sexual selection $\cdot$ Cyanistes caeruleus

\section{Zusammenfassung}

Chemische Analyse zeigt Geschlechtsunterschiede im Bürzeldrüsensekret brütender Blaumeisen

Singvögel sind vor allem für ihren Gesang und ihre Gefiedermerkmale, die bei der sozialen Kommunikation eine bedeutende Rolle spielen, bekannt. Immer mehr Hinweise deuten aber darauf hin, dass viele Vogelarten, darunter auch Singvogelarten, zusätzlich einen gut entwickelten Geruchssinn haben. Welche Bedeutung die geruchliche Kommunikation im sozialen Leben der Vögel, zum Beispiel bei der Partnerwahl, spielt ist allerdings weitgehend noch unbekannt. Das Bürzeldrüsensekret könnte in diesem Zusammenhang einen wichtigen Beitrag zum chemischen Phänotyp der Vögel leisten. In unserer Studie haben wir uns die chemische Zusammensetzung des Bürzeldrüsensekrets der Blaumeise (Cyanistes caeruleus) in der Brutzeit angeschaut. Blaumeisen sind eine viel genutzte Modellart in der Verhaltensforschung und Verhaltensökologie, insbesondere auch in Studien zur sexuellen Selektion und (außerpaarigen) Partnerwahl. Anhand von chemischen Analysen mittels Gas-Chromatographie fanden wir heraus, dass es bei brütenden Blaumeisen einen Geschlechtsunterschied in der Zusammensetzung des Bürzeldrüsensekrets gibt. Weibchen neigen außerdem dazu, eine größere Anzahl von vermeintlichen Substanzen in ihren Sekreten zu haben als Männchen. Wir diskutieren hier kurz die möglichen Implikationen dieser Ergebnisse und spekulieren, dass die chemische Zusammensetzung des Bürzeldrüsensekrets ein sexuell selektiertes Merkmal

Communicated by I. Moore.

Barbara A. Caspers

barbara.caspers@uni-bielefeld.de

Peter Korsten

peter.korsten@uni-bielefeld.de

1 Department of Behavioural Ecology, Bielefeld University, Konsequenz 45, 33615 Bielefeld, Germany
2 Behavioural and Physiological Ecology, Groningen Institute for Evolutionary Life Sciences (GELIFES), University of Groningen, P.O. Box 11103, 9700 CC Groningen, The Netherlands

3 Department of Animal Behaviour, Bielefeld University, Konsequenz 45, 33615 Bielefeld, Germany 
bei Blaumeisen sein könnte. Unsere vorläufigen Ergebnisse rechtfertigen Folgeuntersuchungen, in denen die Identifikation der wichtigsten chemischen Verbindungen des Bürzeldrüsensekrets und die Variation innerhalb und zwischen Individuen in der chemischen Zusammensetzung des Drüsensekrets im Fokus stehen.

\section{Introduction}

Birds are well known and much studied for their use of acoustic and visual signals in intraspecific communication (e.g. Catchpole and Slater 2003; Hill and McGraw. 2006). The possibility that chemicals might also be involved in intraspecific communication has been widely ignored until recently (Roper 1999; Caro et al. 2015). Due to the misbelief that birds, and particularly songbirds, are anosmic (i.e. have no sense of smell) - in combination with the clear presence of acoustic and visual signals used in intraspecific communication-, the existence and functionality of an avian olfactory phenotype has received little attention. This is surprising since chemical communication is omnipresent and can be found across the animal kingdom from one-cell organisms to humans (Müller et al. 2020).

Body odours are predestined to act as infochemicals transferring information about an organism (Müller et al. 2020) and evidence exists for several decades that chemicals are involved in intraspecific communication also in birds (Jacob et al. 1979; Balthazart and Schoffeniels 1979; Kolattukudy et al. 1987). In Mallards (Anas platyrhynchos), for example, females in contrast to males change the composition of the preen gland secretion between the reproductive and non-reproductive season (Jacob et al. 1979) and produce a specific substance during the breeding season only (Kolattukudy et al. 1987). Moreover, male mallards being deprived of their sense of smell showed reduced sexual behaviour compared to those with intact olfactory capabilities (Balthazart and Schoffeniels 1979). Although these early studies demonstrated sex differences in the chemical phenotype and the likely importance of chemicals in social communication in birds, only recently this phenomenon has received more extensive scientific investigation.

The secretion produced by the preen (or uropygial) gland, which is present in almost all bird species, is potentially a primary source of chemical cues in birds (Hagelin 2007). The preen gland-located on the lower back at the basis of the tail-is the only holocrine skin gland present in birds (Jacob and Ziswiler 1982). It releases a waxy, oily secretion that birds transfer onto their plumage during preening. The secretion has long been known to aid waterproofing and the physical integrity of the feathers (Elder 1954; Giraudeau et al. 2010; but see Salibian and Montalti 2009) and to protect them against feather-degrading bacteria (Jacob and Ziswiler 1982; Martín-Platero et al. 2006; Shawkey et al. 2003). Whilst few ornithologists would deny that the preen gland secretion plays an essential role in feather maintenance, this does not preclude other important functions. The secretion consists of a large number of volatile compounds (Campagna et al. 2012), which could potentially be important in intraspecific chemical communication.

The chemical composition of the preen gland secretion has been found to hold information on sex in several species (Jacob et al. 1979; Reneerkens et al. 2007; Martín-Vivaldi et al. 2009; Whittaker et al. 2010; Zhang et al. 2010; Leclaire et al. 2011; Amo et al. 2012a; Mihailova et al. 2014; Tuttle et al. 2014; Grieves et al. 2019b), but not in some others (Reneerkens et al. 2007; Gabirot et al. 2018). In addition, it has been found that the secretion may hold information on age (Shaw et al. 2011), the major histocompatibility complex (Leclaire et al. 2014, 2017; Slade et al. 2016; Grieves et al. 2019b), genetic relatedness (Leclaire et al. 2012; Potier et al. 2018), individual identity (Whittaker et al. 2010) and health status (Grieves et al. 2018; Díez-Fernández et al. 2020). Moreover, behavioural studies have shown that olfactory cues are used in kin recognition (Bonadonna and Sanz-Aguilar 2012; Krause et al. 2012; Caspers et al. 2015, 2017) and influence mate choice (Balthazart and Taziaux, 2009; Caspers et al. 2015; Grieves et al. 2019a, b). Although the number of studies characterising chemical cues potentially involved in intraspecific communication in birds is increasing, we are still only at the beginning of unravelling the information that may be transferred via these chemical cues. This study is aimed at providing a first characterisation of the composition of the preen gland secretion in a wellstudied songbird species, the Blue Tit Cyanistes caeruleus, which is an important model in studies of animal behaviour and ecology (reviewed by Stenning 2018).

There is evidence that Blue Tits have a sense of olfaction (Steiger et al. 2008), which they may use in different situations, such as nest building or social communication (Petit et al. 2002; Mennerat et al. 2009; Rossi et al. 2017). However, although the Blue Tit has long been used as a model particularly in studies of sexual selection and (extra-pair) mate choice (e.g. Kempenaers et al. 1992; Sheldon et al. 1999; Foerster et al. 2003; Korsten et al. 2006; Magrath et al. 2009; Schlicht et al. 2015), it remains unknown whether the chemical phenotype also plays a role in mate choice decisions in this species. To assess whether relevant information might be encoded in the preen gland secretion of Blue Tits, we investigated whether there is a sex difference in the preen gland secretion (i.e. whether the sexes differ in the composition of their preen gland secretion). To this aim, we collected preen gland secretion of male and female breeding Blue Tits and characterised its chemical composition, using gas chromatography. 


\section{Methods}

\section{Study population and field methods}

We collected the preen gland secretion samples in a nest box population of Blue Tits in 'De Vosbergen' near Groningen, The Netherlands, which has been studied since 2001 (Korsten et al. 2006; Amininasab et al. 2016). During the breeding season of 2016, we sampled the preen gland secretion of 33 adult Blue Tits ( $n=13$ males; $n=20$ females), which we captured inside their nest boxes during chick feeding (in May). We sexed the birds based on the presence (=female) or absence $(=$ male) of an incubation patch. For collecting the samples, we used commercially available cotton wool buds ('Jeden Tag Wattestäbchen', Offenburg, Germany), with which we gently massaged the nipple of the birds' preen glands (following e.g. Reneerkens et al. 2002). We stored the cotton wool buds with the preen gland secretion samples in Teflon-capped $20 \mathrm{ml}$ glass vials (Labsolute ${ }^{\circledR}$, Th. Geyer; Fig. 1). In the field, we also created blank samples without preen gland secretion as negative controls by taking the cotton wool buds briefly out of the sample vials (ca. $5 \mathrm{~s}$ ) and placing them back in without sampling a bird ( $n=2$ blank samples). For further details on our standard field procedures, see Korsten et al. (2006). After collection in the field, samples were stored at $-20{ }^{\circ} \mathrm{C}$ (on the day of their collection).

\section{Sample processing and chemical analysis}

At the start of the chemical processing, all samples were defrosted and $200 \mu$ l Dichloromethane (DCM, 99.9\% purity) was added to each sample. Afterwards each sample was vortexed and $50 \mu \mathrm{l}$ of DCM was extracted from the cotton, using a blunt-shaped glass syringe (Hamilton $\odot$, Bonaduz, Switzerland). The extracted samples were directly transferred into a $2 \mathrm{ml}$ (Rotilabo®, Karlsruhe, Germany) glass vial containing a $100 \mu \mathrm{l}$ glass inset. These extracted samples were analysed using gas chromatography with flame-ionisation detection (GC-FID, GC2010, Shimadzu) equipped with a VF-5 ms capillary column (30 m x $0.25 \mathrm{~mm}$ ID, DF 0.25 , $10 \mathrm{~m}$ guard column, Varian Inc., Lake Forest, California, USA). For analysis, $1 \mu \mathrm{l}$ of each sample was injected into a deactivated glass wool-packed liner at an inlet temperature of $250{ }^{\circ} \mathrm{C}$ and processed in a split 10 mode with $20 \mathrm{ml} / \mathrm{min}$ split flow. Hydrogen was used as carrier gas and its flow rate was held at $1 \mathrm{ml} / \mathrm{min}$. The GC temperature started at $50{ }^{\circ} \mathrm{C}$ for an initial time of $3 \mathrm{~min}$, followed by a $10^{\circ} \mathrm{C} / \mathrm{min}$ rate of increase to a final temperature of $280^{\circ} \mathrm{C}$, which was kept for 20 min. A characteristic chromatogram is provided in Fig. 2. All of the chromatograms can be found in the supplementary material. For each chromatogram, the area underneath each

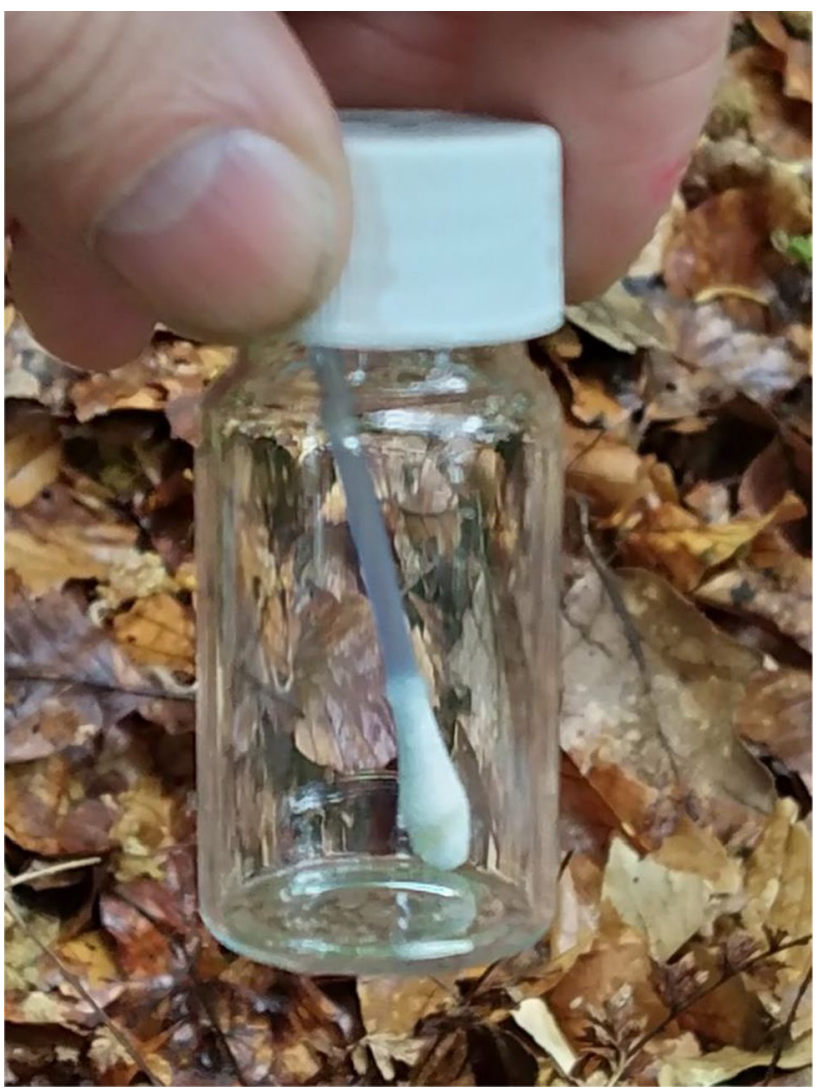

Fig. 1 Glass vial holding a cotton wool bud with a sample of preen gland secretion of a Blue Tit

peak was calculated and used for later analysis. The aim of this study was to investigate whether male and female breeding Blue Tits differ in the composition and diversity of their preen gland secretions. For this aim, we used GC-FID, which does not allow us to identify the single substances. Thus, we currently cannot identify the substances involved. However, this will be our aim in follow-up work.

\section{Statistical analyses}

Before further data analyses, we removed all recordings of putative substances also present in the cotton wool bud blank samples $(n=2)$ and removed all chemical singletons, i.e. substances that were only present in one of the samples (following Stoffel et al. 2015). In total, we found 475 different putative substances (based on retention time), which were recorded in at least 2 of our samples. Substances were aligned using the R package GCAlignR (Ottensmann et al. 2018) ran in $R$ version 4.0.2 ( $R$ Core Team 2020). A large share of the substances $(40 \%, n=193)$ in this dataset were present in fewer than five individuals (Fig. 3a), with 3\% of the substances $(n=16)$ being shared by all 33 individuals. 
Fig. 2 Example chromatogram of the preen gland secretion of a Blue Tit female (chromatogram ID: PK14). All chromatograms can be found in the supplementary material

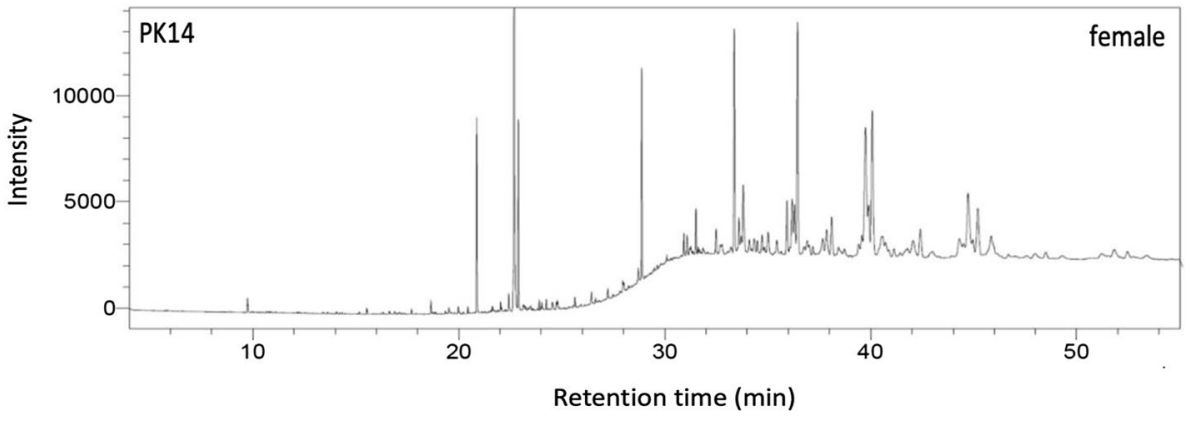

Next, for each sample, we calculated the relative contribution (\%) of each substance to the total peak area of all substances (following Caspers et al. 2009; Leclaire et al. 2012; Stoffel et al. 2015). With this procedure, we ascertained that all chromatograms were comparable on a similar scale, since the total amount of preen gland secretion collected likely differed amongst individuals. Using these data, we compared the chemical diversity between the sexes, specifically the total number of substances, and the Shannon- and SimpsonIndices, by applying Mann-Whitney $U$ tests.

For further analyses, we also created a reduced dataset by omitting all substances that contributed less than $0.1 \%$ to the samples' total peak area (Leclaire et al. 2012; Grieves et al. $2019 b)$. A substance was only removed, if in none of the samples the contribution was larger than $0.1 \%$. This reduced dataset consisted of 154 different putative substances. In the reduced dataset, $10 \%(n=16)$ of substances were shared by all 33 individuals (Fig. 3b) and 12\% of substances $(n=19)$ were shared by fewer than five individuals, giving more weight to those substances present in a larger proportion of the samples. Thereafter, peaks were again standardised by total peak area per individual (Stoffel et al. 2015). We compared the chemical composition between the sexes by computing a pairwise similarity matrix using the Bray-Curtis similarity index on the $\log (\mathrm{x}+1)$ transformed data. Then, we analysed potential differences between a priori defined groups (i.e. the sexes) with a non-parametric permutationbased analysis of similarities (ANOSIM). The ANOSIM is a permutation test that allows for determining whether samples within a priori defined groups are more similar on average than samples between groups. The ANOSIM analyses were performed on the full dataset ( $n=475$ substances) and on the reduced dataset ( $n=154$ substances) using PRIMER 6.1.12 (Primer-E 2000 Ltd., Plymouth, UK). We visualised our data using a non-metric multidimensional scaling plot (nMDS). The nMDS plot gives a two-dimensional representation of the multidimensional matrix of pairwise similarities. The closer two symbols appear on such a plot the more similar the two samples are in their chemical composition. The axes are dimensionless. The significance level was set to 0.05 and we used two-tailed tests throughout.

\section{Results}

The chemical composition of the preen gland secretions differed markedly between the sexes, as shown by the ANOSIM analysis (ANOSIM: Global $R=0.219, p<0.001$; Fig. 4a), i.e. within-sex similarities were higher than between-sex similarities. The same pattern was found when analysing the full dataset of 475 substances (ANOSIM: Global $R=0.274$, $p<0.001)$.

The preen gland secretion of females further tended to contain more putative substances (Mann-Whitney $U$ test; $\mathrm{W}=181.5, p=0.06$; Fig. $2 \mathrm{~b}$ ), with females having 163 putative substances (median) and males 110 (median). There was no difference in the diversity of the substances in the preen gland secretion between the two sexes as measured by
Fig. 3 Histograms showing how many individuals share a specific substance (a) based on the whole dataset $(n=475)$ and (b) based on the reduced subset, considering only substances contributing more than $0.1 \%$ of the total peak area of the samples $(n=154)$ (a)

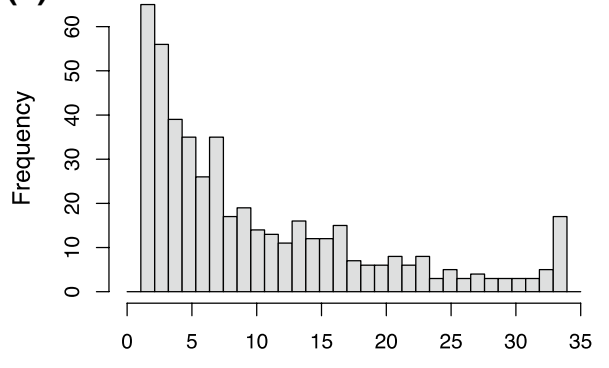

Number of individuals that share a specific substance (b)

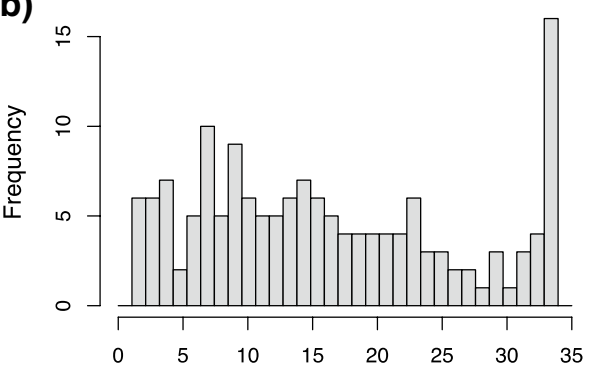

Number of individuals that share a specific substance 

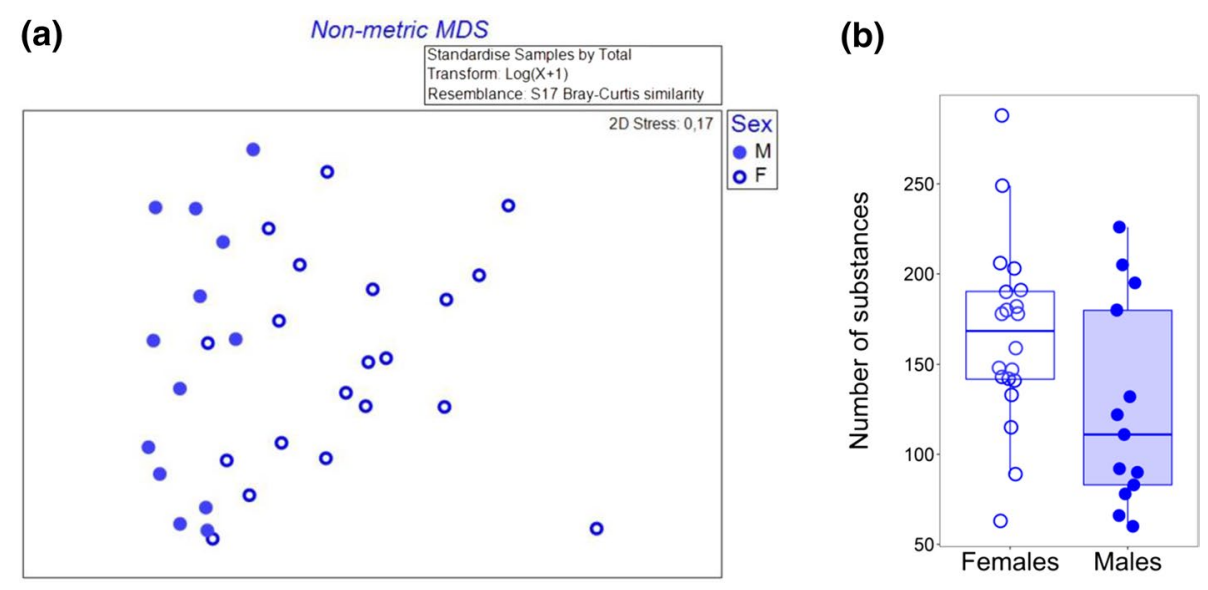

Fig. 4 Blue tits show significant sex differences in the composition (a) of the preen gland secretion with females tending to have a larger number of putative substances (b) in their preen gland secretion. a Non-metric multidimensional scaling (nMDS) plot of similarities between male and female Blue Tit preen gland secretions. Each

the Shannon and Simpson indices (Mann-Whitney $U$ test; Shannon: $\mathrm{W}=148, p=0.52$; Simpson: $W=125, p=0.87$ ).

\section{Discussion}

There is growing evidence that communication via chemicals is important in songbirds (e.g. Caro et al. 2015; Caspers et al. 2017; Grieves et al. 2019a; Whittaker et al. 2019). Blue tits likely have a well-developed sense of smell (Petit et al. 2002; Mennerat et al. 2009; Rossi et al. 2017), which raises the possibility that the chemical phenotype plays a role in intraspecific communication in this common songbird species. In this first explorative study we found significant differences in the chemical composition between males and females. Female secretions further tended to have a larger number of different putative substances compared to the secretions of males. The latter finding is in line with the pattern in the majority of birds studied so far in which females had larger diversities in case of sex differences in the chemical phenotypes (Whittaker and Hagelin 2020).

Functional explanations for a sex difference in preen gland secretion may be a potential role of chemicals from the female preen gland secretion in protecting the eggs from microbes, in suppressing the number of ectoparasites in the nest, or in providing crypsis to avoid olfactory hunting predators. Given that nest building and maintenance as well as incubation of the eggs are largely restricted to the female in Blue Tits, the production of certain molecules that play a role in nest hygiene, or egg and chick, or self-protection (Jacob et al. 1979) might be higher in females compared to males. Protection of eggs or chicks due to the presence of less detectable molecules has been described as the chemical crypsis symbol represents an individual. nMDS plots are dimensionless, the closer two symbols appear on the plot, the more similar the chemical samples are in their composition. The similarity matrix was computed based on the Bray-Curtis Similarity Index. $F$ female, $M$ male. b Box plot of the number of putative substances in females and males

hypothesis (Reneerkens et al. 2005). In ground-breeding sandpipers, for example, it is known that seasonal changes from monoester-fatty-acids to diesters occur only in the incubating sex (Reneerkens et al. 2007). These diesters are less volatile and thus less detectable by olfactory hunting predators (Reneerkens et al. 2005). A larger diversity might not intuitively hint at a less detectable bouquet. However, it is noteworthy that in another songbird species, the dark-eyed junco (Junco hyemalis), female preen gland secretion contains more substances also found in plants, and thus an increased diversity might indeed help to provide chemical camouflage to the nest in its natural environment (Soini et al. 2007).

Another explanation for the sex difference in preen gland composition might be a potential role during intraspecific communication, which has been put forward as the sex semiochemical hypothesis (Grieves 2020). The sex semiochemical hypothesis posits that sex differences in preen gland secretion are associated with reproduction and the odour cues are involved in intraspecific chemical communication. Variation in the composition of the preen gland secretion might be correlated with sex specific characteristics and consequently influence mate choice (Amo et al. 2012a, b; Whittaker et al. 2013, 2018; Grieves et al. 2019b). In darkeyed-juncos, for example, it was found that males with a relatively more 'male-like' odour profile sired more offspring in their own nest, which had a higher survival rate (Whittaker et al. 2013). Preen gland secretions may also provide information on MHC similarity or diversity (Leclaire et al. 2014, 2017; Slade et al. 2016; Grieves et al. 2019a, b) and relatedness (Krause et al. 2012; Leclaire et al. 2012; Potier et al. 2018), which both may also influence mate choice. This would require aspects of the chemical composition to be repeatable within individuals over time, thereby allowing 
for reliable signalling of certain genotypes, something that would need to be further investigated.

In summary, we found sex differences in the chemical phenotype of breeding Blue Tits, in particular in the composition of the preen gland secretion. Furthermore females may have a larger number of different substances in the preen gland secretion (although this result was marginally non-significant). Although at this point we do not know whether the differences between the sexes have an adaptive value, either in protection or intraspecific communication, our finding clearly opens up the possibility that the chemical phenotype carries certain information which could play a role in mate choice. Further research is needed to investigate to what extent the chemical phenotype varies across seasons and within individuals, as well as to identify the main chemical compounds involved.

Supplementary Information The online version contains supplementary material available at https://doi.org/10.1007/s10336-021-01921-w.

Acknowledgements We thank the Kraus-Groeneveld foundation for permission to work at the 'De Vosbergen' estate. We thank A. Hulshof, S. Kloek, P. van Kronenberg, A. Roelofs and S. Zondervan for help with the fieldwork. N. Lilie kindly helped with drawing the graphs. We are grateful to the two anonymous referees for helpful comments on an earlier version of the manuscript.

Funding Open Access funding enabled and organized by Projekt DEAL. This study was financially supported by a Freigeist-Fellowship of the Volkswagen Foundation to BAC.

Data accessibility All data are submitted as supplementary material.

\section{Declarations}

Conflict of interest The authors declare no conflicts of interest.

Ethical standards The study was conducted in full compliance with Dutch law and regulations.

Open Access This article is licensed under a Creative Commons Attribution 4.0 International License, which permits use, sharing, adaptation, distribution and reproduction in any medium or format, as long as you give appropriate credit to the original author(s) and the source, provide a link to the Creative Commons licence, and indicate if changes were made. The images or other third party material in this article are included in the article's Creative Commons licence, unless indicated otherwise in a credit line to the material. If material is not included in the article's Creative Commons licence and your intended use is not permitted by statutory regulation or exceeds the permitted use, you will need to obtain permission directly from the copyright holder. To view a copy of this licence, visit http://creativecommons.org/licenses/by/4.0/.

\section{References}

Amininasab SM, Vedder O, Schut E et al (2016) Influence of fine-scale habitat structure on nest-site occupancy, laying date and clutch size in blue tits Cyanistes caeruleus. Acta Oecologica 70:37-44. https://doi.org/10.1016/j.actao.2015.11.006
Amo L, Avilés JM, Parejo D et al (2012a) Sex recognition by odour and variation in the uropygial gland secretion in starlings. J Anim Ecol 81:605-613. https://doi.org/10.1111/j.1365-2656. 2011.01940.x

Amo L, López-Rull I, Pagán I, Garcia CM (2012b) Male quality and conspecific scent preferences in the house finch, Carpodacus mexicanus. Anim Behav 84:1483-1489. https://doi.org/10.1016/j. anbehav.2012.09.021

Balthazart J, Schoffeniels E (1979) Pheromones are involved in the control of sexual behaviour in birds. Naturwissenschaften 66:5556. https://doi.org/10.1007/BF00369365

Balthazart J, Taziaux M (2009) The underestimated role of olfaction in avian reproduction? Behav Brain Res 200:248-259. https://doi. org/10.1016/j.bbr.2008.08.036

Bonadonna F, Sanz-Aguilar A (2012) Kin recognition and inbreeding avoidance in wild birds: the first evidence for individual kinrelated odour recognition. Anim Behav 84:509-513. https://doi. org/10.1016/j.anbehav.2012.06.014

Campagna S, Mardon J, Celerier A, Bonadonna F (2012) Potential semiochemical molecules from birds: A practical and comprehensive compilation of the last 20 years studies. Chem Senses 37:3-25. https://doi.org/10.1093/chemse/bjr067

Caro SP, Balthazart J, Bonadonna F (2015) The perfume of reproduction in birds: Chemosignalling in avian social life. Horm Behav 68:25-42. https://doi.org/10.1016/j.yhbeh.2014.06.001

Caspers BA, Schroeder FC, Franke S et al (2009) Odour-based species recognition in two sympatric species of sac-winged bats (Saccopteryx bilineata, S. leptura): combining chemical analyses, behavioural observations and odour preference tests. Behav Ecol Sociobiol 63:741-749. https://doi.org/10.1007/s00265-009-0708-7

Caspers BA, Gagliardo A, Krause ET (2015) Impact of kin odour on reproduction in zebra finches. Behav Ecol Sociobiol 69:18271833. https://doi.org/10.1007/s00265-015-1995-9

Caspers BA, Hagelin JC, Paul M et al (2017) Zebra Finch chicks recognise parental scent, and retain chemosensory knowledge of their genetic mother, even after egg cross-fostering. Sci Rep 7:12859. https://doi.org/10.1038/s41598-017-13110-y

Catchpole CK, Slater PJ (2003) Bird song: biological themes and variations. Cambridge University Press

Díez-Fernández A, Martínez-de la Puente J, Gangoso L et al (2020) Mosquitoes are attracted by the odour of Plasmodium-infected birds. Int J Parasitol 50:569-575. https://doi.org/10.1016/j.ijpara. 2020.03.013

Elder WH (1954) The oil gland of birds. Wilson Bull 66:6-31

Foerster K, Delhey K, Johnsen A et al (2003) Females increase offspring heterozygosity and fitness through extra-pair matings. Nature 425:714-717. https://doi.org/10.1038/nature01969

Gabirot M, Buatois B, Müller CT, Bonadonna F (2018) Odour of King Penguin feathers analysed using direct thermal desorption discriminates between individuals but not sexes. Ibis 160:379-389. https://doi.org/10.1111/ibi.12544

Giraudeau M, Duval C, Guillon N et al (2010) Effects of access to preen gland secretions on mallard plumage. Naturwissenschaften 97:577-581. https://doi.org/10.1007/s00114-010-0673-z

Grieves LA, Kelly TR, Bernards MA, MacDougall-Shackleton EA (2018) Malarial infection alters wax ester composition of preen oil in songbirds: Results of an experimental study. Auk 135:767-776. https://doi.org/10.1642/AUK-17-242.1

Grieves L, Gloor G, Bernards M, MacDougall-Shackleton E (2019a) Songbirds show odour-based discrimination of similarity and diversity at the major histocompatibility complex. Anim Behav 158:131-138. https://doi.org/10.1016/j.anbehav.2019.10.005

Grieves LA, Bernards MA, MacDougall-Shackleton EA (2019b) Wax ester composition of songbird preen oil varies seasonally and differs between sexes, ages, and populations. J Chem Ecol 45:37-45. https://doi.org/10.1007/s10886-018-1033-2 
Grieves LA (2020) Chemical communication in songbirds. In: Electronic thesis and dissertation repository, p 6926. https://ir.lib.uwo. ca/etd/6926

Hagelin JC (2007) The citrus-like scent of crested auklets: reviewing the evidence for an avian olfactory ornament. J Ornithol 148:195. https://doi.org/10.1007/s10336-007-0185-6

Hill GE, McGraw KJ (2006) Bird coloration: mechanisms and measurements. Harvard University Press

Jacob J, Ziswiler V (1982) The Uropygial Gland Avian Biol 6:199-324

Jacob J, Balthazart J, Schoffeniels E (1979) Sex differences in the chemical composition of uropygial gland waxes in domestic ducks. Biochem Syst Ecol 7:149-153. https://doi.org/10.1016/ 0305-1978(79)90024-3

Kempenaers B, Verheyen GR, den Broeck MV et al (1992) Extra-pair paternity results from female preference for high-quality males in the blue tit. Nature 357:494-496. https://doi.org/10.1038/35749 $4 \mathrm{a} 0$

Kolattukudy P, Bohnet S, Rogers L (1987) Diesters of 3-hydroxy fatty acids produced by the uropygial glands of female mallards uniquely during the mating season. J Lipid Res 28:582-588

Korsten P, Lessells CM, Mateman AC et al (2006) Primary sex ratio adjustment to experimentally reduced male UV attractiveness in blue tits. Behav Ecol 17:539-546. https://doi.org/10.1093/beheco/ $\operatorname{arj061}$

Krause ET, Krüger O, Kohlmeier P, Caspers BA (2012) Olfactory kin recognition in a songbird. Biol Lett 8:327-329. https://doi.org/ 10.1098/rsbl.2011.1093

Leclaire S, Merkling T, Raynaud C et al (2011) An individual and a sex odor signature in kittiwakes? Study of the semiochemical composition of preen secretion and preen down feathers. Naturwissenschaften 98:615-624. https://doi.org/10.1007/s00114-011-0809-9

Leclaire S, Merkling T, Raynaud C et al (2012) Semiochemical compounds of preen secretion reflect genetic make-up in a seabird species. Proc R Soc B 279:1185-1193. https://doi.org/10.1098/ rspb.2011.1611

Leclaire S, Van Dongen WF, Voccia S et al (2014) Preen secretions encode information on MHC similarity in certain sex-dyads in a monogamous seabird. Sci Rep 4:6920. https://doi.org/10.1038/ srep06920

Leclaire S, Strandh M, Mardon J et al (2017) Odour-based discrimination of similarity at the major histocompatibility complex in birds. Proc R Soc B 284:20162466. https://doi.org/10.1098/rspb. 2016.2466

Magrath MJL, Vedder O, van der Velde M, Komdeur J (2009) Maternal effects contribute to the superior performance of extra-pair offspring. Curr Biol 19:792-797. https://doi.org/10.1016/j.cub. 2009.03.068

Martín-Platero AM, Valdivia E, Ruíz-Rodríguez M et al (2006) Characterization of antimicrobial substances produced by Enterococcus faecalis MRR 10-3, isolated from the uropygial gland of the hoopoe (Upupa epops). Appl Environ Microbiol 72:4245-4249. https://doi.org/10.1128/AEM.02940-05

Martín-Vivaldi M, Ruiz-Rodríguez M, Soler JJ et al (2009) Seasonal, sexual and developmental differences in hoopoe Uрира ерорs preen gland morphology and secretions: evidence for a role of bacteria. J Avian Biol 40:191-205. https://doi.org/10.1111/j.1600048X.2009.04393.x

Mennerat A, Mirleau P, Blondel J et al (2009) Aromatic plants in nests of the blue tit Cyanistes caeruleus protect chicks from bacteria. Oecologia 161:849-855. https://doi.org/10.1007/ s00442-009-1418-6

Mihailova M, Berg ML, Buchanan KL, Bennett ATD (2014) Odourbased discrimination of subspecies, species and sexes in an avian species complex, the crimson rosella. Anim Behav 95:155-164. https://doi.org/10.1016/j.anbehav.2014.07.012
Müller C, Caspers BA, Gadau J, Kaiser S (2020) The power of infochemicals in mediating individualized niches. Trends Ecol Evol 35:981-989. https://doi.org/10.1016/j.tree.2020.07.001

Ottensmann M, Stoffel MA, Nichols HJ, Hoffman JI (2018) GCalignR: An $\mathrm{R}$ package for aligning gas-chromatography data for ecological and evolutionary studies. PLoS ONE 13:1-20. https://doi.org/10. 1371/journal.pone.0198311

Petit C, Hossaert-McKey M, Perret P et al (2002) Blue tits use selected plants and olfaction to maintain an aromatic environment for nestlings. Ecol Lett 5:585-589. https://doi.org/10.1046/j.1461-0248. 2002.00361.x

Potier S, Besnard MM, Schikorski D et al (2018) Preen oil chemical composition encodes individuality, seasonal variation and kinship in black kites Milvus migrans. J Avian Biol 49:e01728. https://doi. org/10.1111/jav.01728

R Core Team (2020) R: a language and environment for statistical computing. In: R foundation for statistical computing. Vienna, Austria

Reneerkens J, Piersma T, Damsté JSS (2002) Sandpipers (Scolopacidae) switch from monoester to diester preen waxes during courtship and incubation, but why? Proc R Soc Lond B 269:21352139. https://doi.org/10.1098/rspb.2002.2132

Reneerkens J, Piersma T, Damsté JSS (2005) Switch to diester preen waxes may reduce avian nest predation by mammalian predators using olfactory cues. J Exp Biol 208:4199-4202. https://doi.org/ $10.1242 /$ jeb.01872

Reneerkens J, Almeida JB, Lank DB et al (2007) Parental role division predicts avian preen wax cycles. Ibis 149:721-729. https://doi.org/ 10.1111/j.1474-919X.2007.00693.x

Roper TJ (1999) Olfaction in birds. Adv Study Behav 28:247-247

Rossi M, Marfull R, Golüke S et al (2017) Begging blue tit nestlings discriminate between the odour of familiar and unfamiliar conspecifics. Funct Ecol 31:1761-1769. https://doi.org/10.1111/ 1365-2435.12886

Salibian A, Montalti D (2009) Physiological and biochemical aspects of the avian uropygial gland. Braz J Biol 69:437-446. https://doi. org/10.1590/S1519-69842009000200029

Schlicht L, Valcu M, Kempenaers B (2015) Spatial patterns of extrapair paternity: beyond paternity gains and losses. J Anim Ecol 84:518-531. https://doi.org/10.1111/1365-2656.12293

Shaw CL, Rutter JE, Austin AL et al (2011) Volatile and semivolatile compounds in gray catbird uropygial secretions vary with age and between breeding and wintering grounds. J Chem Ecol 37:329. https://doi.org/10.1007/s10886-011-9931-6

Shawkey MD, Pillai SR, Hill GE (2003) Chemical warfare? Effects of uropygial oil on feather-degrading bacteria. J Avian Biol 34:345349. https://doi.org/10.1111/j.0908-8857.2003.03193.x

Sheldon BC, Andersson S, Griffith SC et al (1999) Ultraviolet colour variation influences blue tit sex ratios. Nature 402:874-877. https://doi.org/10.1038/47239

Slade JWG, Watson MJ, Kelly TR et al (2016) Chemical composition of preen wax reflects major histocompatibility complex similarity in songbirds. Proc R Soc B 283:20161966. https://doi.org/10. 1098/rspb.2016.1966

Soini HA, Schrock SE, Bruce KE et al (2007) Seasonal variation in volatile compound profiles of preen gland secretions of the darkeyed junco (Junco hyemalis). J Chem Ecol 33:183-198. https:// doi.org/10.1007/s10886-006-9210-0

Steiger SS, Fidler AE, Valcu M, Kempenaers B (2008) Avian olfactory receptor gene repertoires: evidence for a well-developed sense of smell in birds? Proc R Soc B 275:2309-2317. https://doi.org/10. 1098/rspb.2008.0607

Stenning M (2018) The blue tit. Bloomsbury Publishing

Stoffel MA, Caspers BA, Forcada J et al (2015) Chemical fingerprints encode mother-offspring similarity, colony membership, 
relatedness, and genetic quality in fur seals. Proc Natl Acad Sci 112:E5005-E5012. https://doi.org/10.1073/pnas.1506076112

Tuttle EM, Sebastian PJ, Posto AL et al (2014) Variation in preen oil composition pertaining to season, sex, and genotype in the polymorphic white-throated sparrow. J Chem Ecol 40:1025-1038. https://doi.org/10.1007/s10886-014-0493-2

Whittaker DJ, Hagelin JC (2020) Female-based patterns and social function in avian chemical communication. J Chem Ecol 47:4362. https://doi.org/10.1007/s10886-020-01230-1

Whittaker DJ, Soini HA, Atwell JW et al (2010) Songbird chemosignals: volatile compounds in preen gland secretions vary among individuals, sexes, and populations. Behav Ecol 21:608-614. https://doi.org/10.1093/beheco/arq033

Whittaker DJ, Gerlach NM, Soini HA et al (2013) Bird odour predicts reproductive success. Anim Behav 86:697-703. https://doi.org/ 10.1016/j.anbehav.2013.07.025
Whittaker DJ, Rosvall KA, Slowinski SP et al (2018) Songbird chemical signals reflect uropygial gland androgen sensitivity and predict aggression: implications for the role of the periphery in chemosignaling. J Comp Physiol A 204:5-15. https://doi.org/10.1007/ s00359-017-1221-5

Whittaker DJ, Kuzel M, Burrell MJE et al (2019) Chemical profiles reflect heterozygosity and seasonality in a tropical lekking passerine bird. Anim Behav 151:67-75. https://doi.org/10.1016/j. anbehav.2019.03.005

Zhang J-X, Wei W, Zhang J-H, Yang W-H (2010) Uropygial glandsecreted alkanols contribute to olfactory sex signals in budgerigars. Chem Senses 35:375-382. https://doi.org/10.1093/chemse/ bjq025

Publisher's Note Springer Nature remains neutral with regard to jurisdictional claims in published maps and institutional affiliations. 